УДК: 343.35

DOI: https://doi.org/10.32689/2618-0065-2020-1(3)-163-175

Романенко Євген Олександрович, доктор наук 3 державного управління, професор, Заслужений юрист України, Президент Всеукраїнської асамблеї докторів наук з державного управління, проректор, Міжрегіональна Академія управління персоналом, 03039, м. Київ, вул. Фрометівська, 2, тел.: (044) 264-52-54, e-mail: poboss1978@gmail.com

ORCID: 0000-0003-2285-0543

\title{
ЗАКОН ПРО НЕЗАКОННЕ ЗБАГАЧЕННЯ ПОВЕРНУЛИ В РАДУ
}

Анотація. Конституційний суд України 26 лютого 2019 р. прийняв на закритому засіданні рішення про скасування статті Кримінального кодексу України про незаконне збагачення. Після оприлюднення рішення КСУ про неконституційність статті $368^{2}$ Кримінального кодексу про незаконне збагачення виникло багато проблем. У Національному агентстві із запобігання незаконного збагачення на загальну суму понад півмільярда гривень корупції “зависли” 500 декларацій, перевірки яких було запроваджено цього року. Детективи НАБУ і прокурори САП були змушені закрити кримінальні провадження фактами в межах 65 кримінальних проваджень. Рішення КС означає, що всі кримінальні провадженні в частині, що стосується незаконного збагачення цих осіб, будуть закриті. Так само як і справи, які вже слухаються в суді.

Президент України Володимир Зеленський 17 липня 2019 р. вніс до Верховної Ради невідкладний законопроект № 10461 про відновлення відповідальності за незаконне збагачення. Прийняття проекту Закону дасть змогу запровадити правові підстави для притягнення до кримінальної відповідальності осіб, винних у незаконному збагаченні, а також для стягнення в дохід держави необгрунтованих активів осіб, уповноважених на виконання функцій держави або місцевого самоврядування. Відзначено, що 3 метою подолання корупційних проявів і створення ефективної національної системи правосуддя Україною ратифіковано низка міжнародних договорів, зокрема Конвенції ООН проти корупції від 31 жовтня 2003 р., Кримінальної конвенції РС про боротьбу з корупцією від 27 січня 1999 р., Цивільної конвенції РС про боротьбу з корупцією від 4 листопада 1999 року. Ратифікувавши зазначені акти, Україна взяла на себе зобов'язання імплементувати їх рекомендації до національного законодавства шляхом оновлення антикорупційного закону. Для виконання цієї обіцянки нашій державі знадобилось чимало часу, і цей складний процес 3 огляду на активізацію реформування судових органів та правоохоронних структур i зміну процесуального законодавства ще не завершено. 
Ключові слова: незаконне збагачення, корупція, неправомірна вигода, службова особа, антикорупційне законодавство.

Romanenko Yevhen Oleksandrovych, Doctor of Science in Public Administration, Professor, Honored Lawyer of Ukraine, vice-rector, Interregional Academy of Personnel Management, 03039, Kyiv, Str. Frometivska, 2, tel.: (044) 264-52-54, e-mail: poboss1978@gmail.com

ORCID: 0000-0003-2285-0543

\section{LAW ON UNUSECABLE ENRICHMENT RETURNED TO RADA}

Abstract. On February 26, 2019, the Constitutional Court of Ukraine adopted a decision at a closed meeting to repeal the article of the Criminal Code of Ukraine on illegal enrichment. After the publication of the decision of the KSU on the non-constitutionality of Article $368^{2}$ of the Criminal Code on illegal enrichment, many problems arose. The National Agency for the Prevention of Illicit Enrichment, totaling more than half a billion hryvnia of corruption, is "stuck" by 500 declarations, checks of which were introduced this year. NABU detectives and SAP prosecutors were forced to close criminal proceedings with facts within 65 criminal proceedings. The decision of the Constitutional Court means that all criminal proceedings relating to the unlawful enrichment of these persons will be closed. Just like the cases that are already being heard in court.

President of Ukraine Vladimir Zelensky July 17, 2019 submitted to the Verkhovna Rada an urgent bill number 10461 on the restoration of responsibility for illegal enrichment. Adoption of the draft law will allow introducing legal grounds for bringing to criminal responsibility of those guilty of illegal enrichment, as well as for collecting into the state income unjustified assets of persons authorized to perform the functions of the state or local self-government. It was noted that in order to overcome corruption and create an effective national justice system, Ukraine has ratified a number of international treaties, in particular the UN Convention against Corruption of October 31, 2003, the Criminal Law Convention of the Council of Europe on Combating Corruption of January 27, 1999, the Civil Convention of the Council of Europe the fight against corruption of November 4, 1999. By ratifying these acts, Ukraine has undertaken to implement their recommendations to national legislation by updating the anti-corruption law. It took a long time for our state to fulfill this promise, and this difficult process, given the intensification of the reform of the judiciary and law-enforcement structures, and the change in the procedural law, have not yet been completed.

Keywords: illegal enrichment, corruption, undue profit, official, anticorruption legislation. 
Постановка проблеми. Стаття $368^{2}$ Кримінального кодексу про незаконне збагачення у нинішній редакції була прийнята в 2015 році на хвилі створення нової системи антикорупційних органів.[1] Поява цієї норми була потрібна для повноцінного запуску системи електронного декларування, що в свою чергу, було однією з умов отримання Україною безвізового режиму 3 Європейським союзом. Аналогічна вимога була висунута і для продовження співпраці України з кредиторами, в тому числі, і з Міжнародним валютним фондом.

Під незаконним збагаченням малося ся на увазі придбання активів за кошти, легальність походження яких чиновник, депутат або інша посадова особа, яка виконує державні функції, не може довести. За це правопорушення передбачено тюремний термін від двох до десяти років залежно від рівня займаної посади.

В кінці 2017 року група з 59 нардепів звернулася до Конституційного суду (КСУ) з проханням визнати неконституційною статтю про незаконне збагачення. Підпис під документом поставили, зокрема, і самі фігуранти справ за цією статтею. Депутати вказали суду кілька причин того, чому норма про покарання за незаконне збагачення суперечить Основному закону. Головна з них - це нібито те, що вона порушує базовий для правової системи принцип презумпції невинуватості. "Зі статті $368^{2}$ Кримінального кодексу випливає, що обвинувачена в незаконному збагаченні особа вважається винною, поки не доведе свою невинність, навівши докази того, що активи значного розміру були придбані законно", - йдеться у депутатському поданні.

Конституційний суд України 26 лютого 2019 р. прийняв на закритому засіданні рішення про скасування статті Кримінального кодексу України про незаконне збагачення. У своєму рішенні Конституційний суд підкреслив, що протидія корупції має здійснюватися виключно правовими засобами 3 дотриманням конституційних принципів i приписів законодавства, прийнятого відповідно до Конституції.

Після оприлюднення рішення КСУ про неконституційність статті $368^{2}$ Кримінального кодексу про незаконне збагачення виникло багато проблем.

У Національному агентстві із запобігання корупції “зависли” 500 декларацій, перевірки яких було запроваджено цього року. Детективи НАБУ і прокурори САП були змушені закрити кримінальні провадження фактами незаконного збагачення на загальну суму понад півмільярда гривень в межах 65 кримінальних проваджень. Серед осіб, походження статків яких викликає питання на предмет законності джерел походження, - чимало суддів, прокурорів, народних депутатів, колишніх та чинних керівників органів державної влади. Рішення КС означає, що всі кримінальні провадженні в частині, що стосується незаконного збагачення цих осіб, будуть закриті. Так само як і справи, які вже слухаються в суді.

Президент України Володимир Зеленський 17 липня 2019p. вніс до Верховної Ради невідкладний законопроект № 10461 про відновлення 
відповідальності за незаконне збагачення. Законопроект спрямований на відновлення кримінальної відповідальності за незаконне збагачення, а також на введення інституту стягнення в дохід держави необгрунтованих активів осіб, уповноважених на виконання функцій держави або місцевого самоврядування.

Аналіз останніх досліджень i публікацій. Кримінально-правову кваліфікацію незаконного збагачення досліджували такі українські науковці: Л. П. Брич, Д. О. Гарбазей, О. І. Гузоватий, О. П. Денега, О. О. Дудоров, В. М. Киричко, О. О. Книженко, М. В. Кочеров, В. Н. Кубальський, М. І. Мельник, Д. Г. Михайленко, В. Я. Тацій, Т. М. Тертиченко, Р. В. Трофименко, В. І. Тютюгін, М. І. Хавронюк, О. Ю. Шостко. У Єдиному державному реєстрі судових рішень міститься 14 вироків, постановлених у справах про незаконне збагачення. Але ці вироки є актами застосування ст. $368^{2}$ КК України, яка діяла до вступу в силу положень Закону України від 12.02.2015 № 198-VIII. Однак існуюча у чинному законодавстві норма, яка регламентує кримінальну відповідальність за незаконне збагачення, не дає позитивного результату. Причина цього - частково у недосконалій редакції ст. $368^{2}$ КК України «Незаконне збагачення».

Метою статті $є$ розгляд Рішення КС про неконституційність статті $368^{2}$ Кримінального кодексу про незаконне збагачення та проекту президентського закону про відновлення відповідальності за незаконне збагачення.

Виклад основного матеріалу. 3 метою подолання корупційних проявів i створення ефективної національної системи правосуддя Україною ратифіковано низка міжнародних договорів, зокрема Конвенції ООН проти корупції від 31 жовтня 2003 р., Кримінальної конвенції РС про боротьбу 3 корупцією від 27 січня 1999 р., Цивільної конвенції РС про боротьбу 3 корупцією від 4 листопада 1999 року. Ратифікувавши зазначені акти, Україна взяла на себе зобов'язання імплементувати їх рекомендації до національного законодавства шляхом оновлення антикорупційного закону.[2] Для виконання цієї обіцянки нашій державі знадобилось чимало часу, і цей складний процес 3 огляду на активізацію реформування судових органів та правоохоронних структур і зміну процесуального законодавства ще не завершено.

Стаття 368-2 Кримінального кодексу про незаконне збагачення у нинішній редакції була прийнята в 2015 році на хвилі створення нової системи антикорупційних органів. Поява цієї норми було необхідна для повноцінного запуску системи електронного декларування, що в свою чергу, було однією 3 умов отримання Україною безвізового режиму 3 СС. Аналогічна вимога була висунута і для продовження співпраці України 3 кредиторами, зокрема i 3 Міжнародним валютним фондом. Авторами законопроекту були Юрій Луценко, Сгор Соболєв, Віктор Чумак, Дмитро Добродомов, Іван Мельничук, Сергій Лещенко, Іван Крулько, Володимир 
Парасюк та Юрій Дев'ятко. Щоправда, саме формулювання статті запропонувала нардеп від «Народного фронту» Тетяна Чорновол. Профільний комітет, а потім парламент підтримав їі.

Стаття передбачала кримінальну відповідальність за незаконне збагачення у випадку, якщо особа, уповноважена на виконання функцій держави або місцевого самоврядування (топ-посадовці, чиновники, судді, прокурори тощо), отримала у власність активи, що перевищували одну тисячу неоподатковуваних мінімумів доходів громадян (1 млн 850 тис грн, станом на початок цього року), іне може пояснити їх походження. Максимальне покарання - до 10 років з обмеженням права обіймати певні посади або займатися певною діяльністю до трьох років 3 конфіскацією майна.

Через два роки після ухвалення цієї статті 59 парламентарів, в більшості у складі депутатів «Народного фронту» (23 - від «Народного фронту», 11 БПП, 11 - «Відродження», 3 - «Воля народу», 10 - Опоблоку), подали скаргу в КС. Представником групи ініціаторів був нардеп від «НФ», перший заступник голови Регламентного комітету Павло Пинзеник. Пинзеник, до слова, неодноразово зазначав, що більшість ініційованих НАБУ кримінальних проваджень щодо, зокрема, незаконного збагачення, недостовірного декларування - мають політичний характер.

Результати дослідження проведеного аудиторською компанією Ernst \& Young в період з листопада 2016 року по січень 2017 року, опубліковані в квітні 2017 року, показали що країна за два роки піднялася з сьомого на перше місце за рівнем корупції серед 41 країни з Свропи, Близького Сходу, Індії та Африки із розвиненими ринками чи ринками, що розвиваються. За даним показником Україна знаходилась на найнижчих позиціях серед усіх країн-учасниць дослідження ЕY.В той же час серед країн з розвиненими ринками Данія, Норвегія і Фінляндія мають найнижчі прояви корупції в бізнесі.[3]

Конституційний Суд України 26 лютого 2019 р. ухвалив Рішення у справі за конституційним поданням 59 народних депутатів України щодо відповідності Конституції України (конституційності) статті $368^{2}$ Кримінального кодексу України (далі - Кодекс). Цим Рішенням Суд визнав такою, що не відповідає Конституції України (є неконституційною), статтю $368^{2}$ Кодексу.[4]

У своєму Рішенні Конституційний Суд підкреслив, що протидія корупції має здійснюватися виключно правовими засобами 3 дотриманням конституційних принципів та приписів законодавства, ухваленого відповідно до Конституції України. За приписами статей 62, 63 Конституції України законодавче формулювання складу такого злочину, як незаконне збагачення, не може: покладати на особу обов'язок підтверджувати доказами законність підстав набуття нею у власність активів, тобто доводити свою невинуватість; надавати стороні обвинувачення право вимагати від особи підтвердження 
доказами законності підстав набуття нею у власність активів; уможливлювати притягнення особи до кримінальної відповідальності лише на підставі відсутності підтвердження доказами законності підстав набуття нею у власність активів.

Конституційний Суд України вважає, що дотримання вимоги ясності i недвозначності норм, які встановлюють кримінальну відповідальність, $є$ особливо важливим з огляду на специфіку кримінального закону та наслідки притягнення до кримінальної відповідальності, адже притягнення до такого виду юридичної відповідальності пов'язане 3 можливими істотними обмеженнями прав і свобод людини. Так, стаття $368^{2}$ Кодексу передбачає, зокрема, застосування такого виду покарання, як позбавлення волі на певний строк. Крім того, до осіб, які підозрюються або обвинувачуються у вчиненні злочину, передбаченого названою статтею Кодексу, можуть бути застосовані, зокрема, такі запобіжні заходи, як домашній арешт та тримання під вартою, що пов'язані з обмеженням волі.

«Конституційний Суд України дійшов висновку, що стаття $368^{2}$ Кодексу не відповідає вимогам чіткості, точності й однозначності, а тому суперечить юридичній визначеності як складовій принципу верховенства права, закріпленого у статті 8 Конституції України», - йдеться у Рішенні Суду.

У Рішенні Конституційний Суд України зазначає, що стаття $368^{2}$ Кодексу не узгоджується 3 конституційним принципом презумпції невинуватості (частини перша, друга, третя статті 62 Конституції України) та 3 конституційним приписом щодо неприпустимості притягнення особи до відповідальності за відмову давати показання або пояснення щодо себе, членів сім’і чи близьких родичів (право особи не давати показання або пояснення щодо себе, членів сім’і чи близьких родичів) (частина перша статті 63 Конституції України).

Конституційний Суд України наголошує, що конституційні приписи щодо презумпції невинуватості та неприпустимості притягнення особи до відповідальності за відмову давати показання або пояснення щодо себе, членів сім'ї чи близьких родичів мають застосовуватися рівною мірою до всіх осіб. Конституція України не допускає звуження чи скасування вказаних гарантій стосовно окремих категорій осіб.

Конституційний Суд України зауважує, що положення статті $368^{2}$ Кодексу сформульовані так, що сумніви стосовно законності підстав набуття особою у власність активів у значному розмірі можуть тлумачитися не на користь цієї особи та можуть розглядатися як підтвердження іï незаконного збагачення, хоча відповідно до частини третьої статті 62 Конституції України «усі сумніви щодо доведеності вини особи тлумачаться на їі користь».

Законодавче визначення незаконного збагачення як злочину за умови, якщо сторона обвинувачення не виконує свого обов'язку збирати докази законності підстав набуття особою у власність активів у значному розмірі, уможливлює перекладення цього обов'язку зі сторони обвинувачення 
(держави) на сторону захисту (підозрюваного або обвинуваченого), що є неприпустимим 3 огляду на конституційний принцип презумпції невинуватості, оскільки в такому разі порушується припис частини другої статті 62 Конституції України щодо неприпустимості покладання на особу обов'язку доводити свою невинуватість у вчиненні злочину, тобто право обвинуваченої особи не доводити свою невинуватість у вчиненні злочину.

У Рішенні Суду зазначається, що суттєвим недоліком законодавчого визначення незаконного збагачення як злочину є також те, що в його основу покладено не підтвердження доказами законності підстав набуття у власність активів у значному розмірі. Така вразлива законодавча конструкція статті $368^{2}$ Кодексу уможливлює притягнення до кримінальної відповідальності за незаконне збагачення особи, яка на законних підставах набула активи у власність, але не має підтвердження законності підстав такого набуття. Відсутність підтвердження доказами законності підстав набуття активів у власність згідно зі статтею $368^{2}$ Кодексу може розглядатися як доказ незаконності набуття у власність активів, а дії їх власника - кваліфікуватися як незаконне збагачення. Водночас відсутність підтвердження доказами законності підстав набуття активів у власність не означає підтвердження незаконності цих підстав, а отже, й доведеності вини особи у незаконному збагаченні. Таким чином, законодавче визначення такого злочину, як незаконне збагачення, дає змогу обгрунтовувати обвинувачення особи у незаконному збагаченні на припущеннях навіть тоді, коли йдеться про особу, яка законно набула у власність певні активи.

У своєму Рішенні Конституційний Суд України підкреслює, що поєднання в диспозиції статті $368^{2}$ Кодексу матеріальних та процесуальних приписів $€$ неприйнятним та неприпустимим з огляду на те, що регламентація процесу доказування в кримінальному провадженні належить виключно до сфери кримінального процесуального законодавства. Процесуальні юридичні приписи (підтвердження чи не підтвердження доказами, доведеність чи недоведеність певного факту) не можуть бути складовою юридичної норми, яка передбачає кримінальну відповідальність, оскільки вони пов'язані не 3 діянням суб'єкта злочину, а 3 процесуальною діяльністю посадових осіб уповноважених державних органів.

Конституційний Суд України вважає, що вимога «раціонального пояснення» чи «раціонального обгрунтування» невідповідності між вартістю активів, набутих у власність особою, уповноваженою на виконання функцій держави або місцевого самоврядування, та задекларованими нею законними доходами може бути встановлена законом як вимога підтвердження доброчесності посадової особи та як превентивний засіб у боротьбі 3 корупцією. Однак, з огляду на положення статті 62 Конституції України, така вимога не може встановлюватися законом як обов'язок особи доводити свою невинуватість у вчиненні злочину та надавати докази в межах кримінального провадження. Разом з тим, обов'язок доведення вини посадової особи у 
вчиненні такого злочину, як незаконне збагачення, має покладатися законом лише на державні органи, уповноважені процесуальним законом.

Конституційний Суд України наголошує, що протидія корупції в Україні $\epsilon$ завданням виняткового суспільного та державного значення, a криміналізація незаконного збагачення - важливим юридичним засобом реалізації державної політики у цій сфері. Водночас при визначенні злочином такого діяння, як незаконне збагачення, треба обов'язково враховувати конституційні положення, якими встановлено принципи юридичної відповідальності, права і свободи людини і громадянина, а також їх гарантії.

Конституційний Суд України звертає увагу на те, що такий підхід до криміналізації незаконного збагачення передбачено Конвенцією Організації Об’єднаних Націй проти корупції 2003 року, ратифікованою Верховною Радою України 18 жовтня 2006 року. Статтею 20 Конвенції встановлено, що «за умови дотримання своєї конституції та основоположних принципів своєї правової системи кожна держава-учасниця цієї конвенції розглядає можливість вжиття таких законодавчих та інших заходів, які можуть бути необхідними для визнання злочином умисного незаконного збагачення, тобто значного збільшення активів посадової особи органу публічної влади, яке перевищує їі законні доходи, які вона не може раціонально обгрунтувати». Таким чином, за вказаною конвенцією держава-учасниця розглядає можливість криміналізації незаконного збагачення «за умови дотримання своєї конституції та основоположних принципів своєї правової системи».[4]

Це Рішення КС викликало негативну реакцію у міжнародного співтовариства. У спільній заяві G7 та Світового банку відзначається, що це значна поразка у боротьбі з корупцією в Україні. Це послабило вплив всієї антикорупційної архітектури, включно 3 Вищим антикорупційним судом, який незабаром, має бути створений i, як очікувалося, мав винести рішення щодо значної кількості справ про незаконне збагачення, а також вплинуло на спроможність Національного антикорупційного бюро розслідувати корупцію у вищих ешелонах влади. G7 та Світовий банк закликали українську владу активізувати свої зусилля для забезпечення ефективності антикорупційних правових інструментів та інституцій, а також знайти спосіб продовжити десятки розслідувань та кримінальних переслідувань, завершення яких було поставлене під загрозу цією постановою.[5]

Антикорупційна ініціатива EUACI - найбільша програма технічної допомоги СС в боротьбі з корупцією в Україні - опублікувала висновок про конституційність статті Кримінального кодексу про незаконне збагачення, яку скасував Конституційний суд. EUACI спростовує аргументи КСУ. "У конституційному поданні не досліджуються сутність та релевантність відповідних правових принципів щодо норми Кримінального кодексу, яка заперечується, а також не проводиться поглиблений аналіз відповідної прецедентної практики Свропейського суду з прав людини (ЄСПЛ) або іноземної конституційної практики. Можна стверджувати, що конституційне 
подання також неправильно тлумачить правову норму Кримінального кодексу, яка заперечується, та ігнорує презумпцію конституційності й, таким чином, останній доступ до можливостей тлумачити цю норму кримінального права способом, що був би сумісний з конституційними вимогами", - сказано в документі.[6] "3 конкретного формулювання злочину незаконного збагачення в Україні та судової практики ЄСПЛ і конституційних судів інших держав випливає, що стаття $368^{2}$ КК не передбачає будь-якого перекладання тягаря доказування i, таким чином, не порушує презумпцію невинуватості", - зазначають у EUACI. "Статтю $368^{2}$ КК слід тлумачити в світлі інших положень КК, що встановлює загальні правила застосування кримінального права в часі. За результатами такого тлумачення немає підстав стверджувати, що визначення незаконного збагачення передбачає застосування закону зі зворотною силою", - аргументують в EUACI.[6]

Президент України Володимир Зеленський 17 липня 2019 р. вніс до Верховної Ради невідкладний законопроект № 10461 про відновлення відповідальності за незаконне збагачення.[3] Так в Кримінальний кодекс пропонується доповнити Статтю $368^{5}$ «Незаконне збагачення». Це набуття особою, уповноваженою на виконання функцій держави або місцевого самоврядування, активів, вартість яких більш ніж на дванадцять тисяч неоподатковуваних мінімумів доходів громадян (11,5 млн гр.) перевищує іï доходи - карається позбавленням волі на строк від п'яти до десяти років 3 позбавленням права обіймати певні посади чи займатися певною діяльністю на строк до трьох років.

Примітка. 1. Особами, уповноваженими на виконання функцій держави або місцевого самоврядування, є особи, зазначені у пункті 1 частини першої статті 3 Закону України "Про запобігання корупції".

2. Під набуттям активів слід розуміти набуття їх особою, уповноваженою на виконання функцій держави або місцевого самоврядування, у власність, а також набуття активів у власність чи володіння іншою фізичною або юридичною особою за рахунок, за згодою чи за розпорядженням особи, уповноваженої на виконання функцій держави або місцевого самоврядування.

3. Під активами слід розуміти грошові кошти (у тому числі, готівкові кошти, кошти, що знаходяться на банківських рахунках чи на зберіганні у банках або інших фінансових установах), інше майно, майнові права, нематеріальні активи, обсяг зменшення фінансових зобов'язань, а також роботи чи послуги, надані особі, уповноваженій на виконання функцій держави або місцевого самоврядування.

4. Під доходом особи, уповноваженої на виконання функцій держави або місцевого самоврядування, слід розуміти всі види доходів, отриманих нею (нарахованих їй) із додержанням вимог та обмежень, встановлених Законом України "Про запобігання корупції". 
5. При визначенні різниці між вартістю набутих активів та доходами не враховуються активи, які є предметом провадження у справах про визнання активів необгрунтованими та їх стягнення в дохід держави, а також активи стягнуті в дохід держави в рамках такого провадження.

Законопроектом також пропонується на законодавчому рівні вирішити питання забезпечення належного функціонування інституту стягнення необгрунтованих активів чиновників. Тому передбачається введення до Цивільного кодексу України окремого підстави для припинення права власності, визначення видів активів, які можуть визнаватися необгрунтованими, і межа вартості таких активів (вартість, яка в 500 і більше разів перевищує розмір прожиткового мінімуму для працездатних осіб).

Крім того, уточнюється обов'язок доказування у справах такої категорії. Зокрема, визначається предмет доказування для позивача, що є гарантією захисту прав осіб, щодо яких можуть бути подані відповідні позови.

Положеннями законопроекту в частині введення процедури визнання активів необгрунтованими i їх стягнення пропонується закріпити класичний стандарт доказування - "перевага доказів" (preponderance of the evidence), який закріплює принцип рівності сторін.

За результатами визнання необгрунтованими активів осіб, уповноважених на виконання функцій держави або місцевого самоврядування, i стягнення таких активів пропонується передбачити звільнення зазначених осіб від займаних посад шляхом внесення змін до законів "Про попередження корупції", "Про державну службу", "Про місцеве самоврядування", а також Кодексу законів про працю України.

Справи про визнання необгрунтованими активів та їх стягнення в дохід держави розглядаються Вищим антикорупційним судом, та переглядаються його Апеляційною палатою. Нагадаємо, суд запрацює 35 вересня. Справи розглядаються колегією у складі трьох суддів, один із яких має стаж роботи на посаді судді не менше п'яти років, крім випадків, коли жоден суддя у цьому суді не може брати участь у розгляді справи з передбачених законом підстав.

Саме позивач (представник НАБУ) зобов'язаний навести фактичні дані, які підтверджують зв'язок активів з особою, уповноваженою на виконання функцій держави або місцевого самоврядування, та їх необгрунтованість, тобто наявність різниці між вартістю активів та доходами цієї особи. У разі наведення таких даних доказування факту обгрунтованості активів покладається на відповідача.

У справах про визнання необгрунтованими активів та їх стягнення в дохід держави суд виносить рішення на користь тієї сторони, докази якої були більш переконливими порівняно з доказами іншої сторони.

Забезпечення доказів здійснюється Вищим антикорупційним судом за заявою Національного антикорупційного бюро України, Спеціалізованої 
антикорупційної прокуратури, а у деяких випадках - також Генеральної прокуратури України.

Позов про визнання необгрунтованими активів та їх стягнення в дохід держави подається представником Національного антикорупційного бюро України за погодженням із прокурором Спеціалізованої антикорупційної прокуратури. У справах, де відповідачем є директор, заступник, працівник (особа начальницького складу, державний службовець) НАБУ, прокурор Спеціалізованої антикорупційної прокуратури, звернення до суду та представництво інтересів держави у суді здійснюється прокурорами ГПУ за дорученням Генерального прокурора.

Позов пред'являється щодо необгрунтованих активів:

- набутих протягом трьох років до дня набрання чинності президентським Законом, якщо різниця між вартістю активів і доходами особи, у 500 і більше разів перевищує розмір прожиткового мінімуму для працездатних осіб;

- набутих після набрання чинності цим Законом, якщо різниця у $500 \mathrm{i}$ більше разів перевищує розмір прожиткового мінімуму для працездатних осіб, встановленого законом на день набрання чинності названим вище Законом, але не перевищує межу, встановлену у статті $368^{5}$ Кримінального кодексу України.

Висновки. Необхідність відновлення кримінальної відповідальності за незаконне збагачення виникла внаслідок рішення Конституційного Суду України щодо визнання положень статті $368^{2}$ Кримінального кодексу України такими, що не відповідають Конституції України.

При цьому відсутність кримінальної відповідальності за незаконне збагачення нівелює роль системи електронного декларування у попередженні та виявленні корупції, оскільки для суб'єктів декларування відсутні правові перешкоди для декларування незаконно набутого майна. Крім того, на сьогодні декларування може бути використано для легалізації активів, набутих незаконним шляхом. Запровадження ж інституту визнання необгрунтованими активів осіб, уповноважених на виконання функцій держави або місцевого самоврядування, та стягнення таких активів у дохід держави буде відповідати кращим світовим практикам боротьби із корупцією. Прийняття проекту Закону, внесеному президентом, дасть змогу запровадити правові підстави для притягнення до кримінальної відповідальності осіб, винних у незаконному збагаченні, а також для стягнення в дохід держави необгрунтованих активів осіб, уповноважених на виконання функцій держави або місцевого самоврядування.

\section{Jimepamypa:}

1.Про внесення змін до деяких законодавчих актів України щодо забезпечення діяльності Національного антикорупційного бюро України та Національного агентства з питань запобігання корупції. Закон України від 12 лютого 2015 року № 198-VIII. 
2.Романенко С.О., Чаплай I.В Європейський досвід у сфері протидії корупції та можливість його використання в Україні/Адаптація правової системи України до права Європейського Союзу: теоретичні та практичні аспекти: матеріали Всеукраїнської науково-практичної конференції (м. Полтава, 8 грудня 2016 року) : у 2 ч. - Полтава: ПУЕТ, 2016. - Ч .1. - c.65-67.

3.Romanenko Y.A., Shchokin R.G. Corruption independence in Ukraine //Public management: collection. - № 4 (9) - September 2017. - Kyiv: ДП “Видавничий дім “Персонал”, 2017. - р.182 -194.

4.Рішення Конституційного Суду України у справі за конституційним поданням 59 народних депутатів України щодо відповідності Конституції України (конституційності) статті $368^{2}$ Кримінального кодексу України від 26 лютого 2019 року №1-p/2019.

5. https://twitter.com/G7AmbReformUA/status/1102510773472059392?s=19

6. https://www.unian.ua/politics/10462986-v-yevrosoyuzi-sprostuvali-argumenti-ksushchodo-skasuvannya-statti-pro-nezakonne-zbagachennya.html

7. http://w1.c1.rada.gov.ua/pls/zweb2/webproc4_1?pf3511=66223

\section{References:}

1. Zakon Ukrainy "Pro vnesennia zmin do deiakykh zakonodavchykh aktiv Ukrainy shchodo zabezpechennia diialnosti Natsionalnoho antykoruptsiinoho biuro Ukrainy ta Natsionalnoho ahentstva z pytan zapobihannia koruptsii” : vid 12 liutoho 2015 roku № 198-VIII [Law of Ukraine "On amendments to some legislative acts of Ukraine regarding the provision of activities of the National Anti-Corruption Bureau of Ukraine and the National Agency for the Prevention of Corruption” from February 12, 2015, № 198-VIII]. (n.d.). zakon.rada.gov.ua. Retrieved from https://zakon.rada.gov.ua/laws/show/198-19 [in Ukrainian].

2. Romanenko, Ye. O., Chaplai, I. V. (2016). Yevropeiskyi dosvid u sferi protydii koruptsii ta mozhlyvist yoho vykorystannia $\mathrm{v}$ Ukraini [European experience in the field of combating corruption and the possibility of its use in Ukraine]. Adaptatsiia pravovoi systemy Ukrainy do prava Yevropeiskoho Soiuzu: teoretychni ta praktychni aspekty - Adaptation of the legal system of Ukraine to European Union law: theoretical and practical aspects: Proceedings of the All-Ukrainian Scientific and Practical Conference (Vols. 1). (pp. 65-67). Poltava: PUET [in Ukrainian].

3. Romanenko, Y. A., Shchokin, R. G. (2017). Corruption independence in Ukraine Public management, 4(9), 182-194 [in English].

4. Rishennia Konstytutsiinoho Sudu Ukrainy u spravi za konstytutsiinym podanniam 59 narodnykh deputativ Ukrainy shchodo vidpovidnosti Konstytutsii Ukrainy (konstytutsiinosti) statti 3682 Kryminalnoho kodeksu Ukrainy vid 26 liutoho 2019 roku № 1-r/2019 [Decision of the Constitutional Court of Ukraine in the case on the constitutional submission of 59 people's deputies of Ukraine regarding the conformity of the Constitution of Ukraine (constitutionality) with Article 3682 of the Criminal Code of Ukraine of February 26, 2019, № 1-r / 2019]. (n.d.). zakon.rada.gov.ua. Retrieved from https://zakon.rada.gov.ua/laws/show/v001p710-19 [in Ukrainian].

5. Spilna zaiava G7 ta Svitovoho banku stosovno rishennia Konstytutsiinoho sudu shchodo nezakonnoho zbahachennia [Joint statement by the G7 and the World Bank on the decision of the Constitutional Court on illicit enrichment]. (March 4, 2019). twitter.com. Retrieved from https://twitter.com/G7AmbReformUA/status/1102510773472059392?s=19 [in Ukrainian].

6. V Yevrosoiuzi sprostuvaly arhumenty KSU shchodo skasuvannia statti pro nezakonne zbahachennia [The European Union has rejected the CCS's arguments for abolishing the article on illegal enrichment]. (February 28, 2019). www.unian.ua. Retrieved from 
https://www.unian.ua/politics/10462986-v-yevrosoyuzi-sprostuvali-argumenti-ksu-shchodoskasuvannya-statti-pro-nezakonne-zbagachennya.html [in Ukrainian].

7. Proekt Zakonu pro vnesennia zmin do deiakykh zakonodavchykh aktiv Ukrainy shchodo konfiskatsii nezakonnykh aktyviv osib, upovnovazhenykh na vykonannia funktsii derzhavy abo mistsevoho samovriaduvannia, i pokarannia za nabuttia takykh aktyviv vid 17.07.2019, № 10461 [Draft Law on Amendments to Certain Legislative Acts of Ukraine on Confiscation of Illegal Assets of Persons Authorized for State or Local Government Functioning and Punishment for Acquiring Such Assets from 17.07.2019, № 10461]. (n.d.). zakon.rada.gov.ua. Retrieved from http://w1.c1.rada.gov.ua/pls/zweb2/webproc4_1?pf3511=66223 [in Ukrainian]. 